\title{
Comparison of Seed Corn Single Crosses SC 704 and SC 770 Response to Different Plant Densities and Nitrogen Levels
}

\author{
Esmaeil Yasari \\ Agriculture Department, Payame Noor University, 19395-4697, Tehran, Iran \\ E-mail: e_yassari@yahoo.com \\ Mohammad Reza Noori \\ Department of Agronomy and Plant Breeding, Faculty of Agricultural and Natural Resources \\ Islamic Azad University, Qaemshahr Branch, Qaemshahr, Mazandaran, Iran \\ E-mail:mn48@yahoo.com
}

Mohammad Hossein Haddadi

Agriculture and Natural Research Center of Mazandaran, Gharakheil Agronomy Research Station Ghaemshahr, Iran

Received: February 6, 2012

Accepted: February 23, $2012 \quad$ Online Published: April 1, 2012

doi:10.5539/jas.v4n5p263

URL: http://dx.doi.org/10.5539/jas.v4n5p263

\begin{abstract}
An experiment was conducted at the Research Station of Gharakheil of Mazandaran Province, Iran, to evaluate the response of seed corn single crosses SC 704 and SC 770 to different plant densities and nitrogen levels during summer 2010. The soil at the site of the experiment had a loamy texture consisting of $48 \%$ sand, $35 \%$ silt, and $17 \%$ clay, with $\mathrm{pH}$ of 7.81 , and electrical conductivity of $0.55 \mathrm{mmohs} / \mathrm{cm}$. The experiment was performed in the form of factorial-split using the randomized complete block design. The main factor investigated was the two corn cultivars of Single Cross 704 and Single Cross 770. The sub-factors included three levels of applied nitrogen: the control treatment $\mathrm{B} 1$ receiving no nitrogen, treatment $\mathrm{B} 2$ receiving $250 \mathrm{Kg}$ nitrogen per hectare and treatment $\mathrm{B} 3$ receiving $350 \mathrm{Kg}$ of nitrogen per hectare, along with three plant density levels were $\mathrm{C} 1, \mathrm{C} 2$, and $\mathrm{C} 3$, with 75000, 85000, and 95000 plants per hectare, respectively. Results showed that the effect of the cultivar on the trait of grain yield was significant at the probability level of 5 percent. Comparison of the means showed that the cultivar Single Cross 704 with a yield of 12138 Kg.h was superior to the cultivar Single Cross 770 (which had a yield of $10877 \mathrm{Kg} . \mathrm{h})$. Comparison of the means of nitrogen levels indicated that the highest yield (12310 $\mathrm{kg} . \mathrm{h})$ was achieved with the application of $350 \mathrm{~kg} . \mathrm{h}$ of nitrogen and the lowest $(10500 \mathrm{~kg} . \mathrm{h})$ was obtained in the control treatment. Comparison of the means of the cultivars with respect to the number of seed rows suggested that the cultivar Single Cross 704 with 15.28 seed rows was superior to the cultivar Single Cross 770 with 14.96 seed rows. The rate of nitrogen application had no significant effects on the number of seed rows. The maximum and the minimum numbers of seed rows of 15.74 and 14.48 were observed at densities of 75000 and 95000 plants per hectare, respectively. Results of individual correlation coefficients of the traits studied suggest that seed yield has the strongest positive and significant correlation with the trait of the $1000-$ seed weight $\left(0.539^{*}\right)$, with the corn ear length $\left(0.52^{*}\right)$, and with the number of seed rows per corn ear $(0.453 *)$. It was also found that the 1000-seed weight had the strongest positive and significant correlation with the diameter of corn ears $\left(0.700^{*}\right)$, the length of corn ears $\left(0.386^{*}\right)$, and the number of seed rows per corn ear $\left(0.367^{*}\right)$. Furthermore, the number of seeds per corn ear had the strongest positive and significant correlation with the features of the number of seeds per seed row $\left(0.882^{*}\right)$, the length of the corn ears $\left(0.737^{*}\right)$, and the number of seed rows per ear $\operatorname{corn}\left(0.457^{*}\right)$.
\end{abstract}

Keyword: Corn, Cultivar, Nitrogen, Plant density 


\section{Introduction}

Corn (Zea mays L.), is a valuable crop plant the variety, good adaptability, and high food value of which have ranked it as one of the most important crop plants of the world (Noormohammadi , 1997). For 4500 years, corn has had a special and importance role in the lives, the religious rituals and customs, and the development of the cultural history of the peoples of South, Central, and North Americas (Kiniry et al., 1992). Considering the ever increasing need of societies to provide the corn required for feeding stock and birds, a lack of research on this crop is felt. Because of its short growing season, and due to its higher yield under different weather conditions as compared with other crops, this valuable crop ranks third in the world, after wheat and rice, with respect to acreage under cultivation (Anonymous, 2003). Since the yearly consumption of corn in Iran amounts to 3 million tons, and in 2004 a total of 2 million tons was harvested from about 300000 hectares of land under its cultivation, we still have a lot of problems to solve in order to achieve self sufficiency and to stop the import of this crop. Therefore, the development and extension of this strategic crop is important (The corn bureau of the Ministry of Agricultural Jihad, 2005).

Hybrid cultivars differ from each other in yield due to differences in their adaptability to the environment. In this regard, the climatic conditions, the potential of the region, the soil fertility, and the soil depth have an effect almost similar to that of salinity (Seyyedehvand et al., 2000). One of the most important factors in improving cultural practices in corn, which is a factor that influences grain corn yield, is the plant density per unit area of land (with each cultivar having different plant densities in different climates according to the prevailing temperature and radiation) (Natarajian et al., 1989).

Ajamnouroozi and Bohrani (1998) reported that the changes in yield occurring with increases in plant densities were ascending at first and then descending, that changes in grain yield are actually in the form of a parabola, that yield limitations at low plant densities are brought about by the shortage of plants and at high plant densities by the sterility of the plants, and that plant density in each region is determined by the competition of the plants for obtaining water, light, and nutrients. Kresovic et al. (1997) reported that with an increase in plant density from 49300 to 59500 plants per hectare, grain yield went up from 11.14 to 15.02 tons per hectare. Nielson (1988) reported that with an increase in plant density from 44444 to 88888 plants per hectare, corn yield rose by about 2.7 percent. In addition to water stress, shortage of nitrogen required by the plants can also apply added pressure on the growth and the yield of corn. Scientists believe mismanagement in irrigation and shortage of nitrogen are the main factors causing a reduction in corn yield. In many studies, the positive effect of nitrogen in increasing grain yield, the number of seeds per corn ear, and the weight of each seed of different corn hybrids has been emphasized (Osborne et al., 2002). Under conditions of water shortage in the soil, in which nutrient absorption, especially nitrogen absorption, is reduced, it appears that there should be a correspondence between the available water in the soil and the nitrogen applied. This will, on the one hand, reduce the cost of corn production and, on the other hand, will prevent the unnecessary application of nitrogen, which is not usually accompanied by an increase in yield (Solan et al., 1990).

Therefore, in this research, we studied the effects of plant density and nitrogen application on some of the qualitative and quantitative traits of silage corn cultivars.

\section{Materials and Methods}

In the summer of 2010, an experiment was conducted at the Research Station of Gharakheil (in the city of Ghaemshahr), which is affiliated with the Agriculture and Natural Resources Research Center of the Province of Mazandaran, and which has a latitude of $36^{\circ} 27^{\prime}$ North, a longitude of $52^{\circ} 53^{\prime}$ East, and an altitude of 14.73 meters above sea level. After selecting the land, it was prepared (plowed, disked, and leveled), and soil samples were taken at depths of from zero to 30 centimeters to determine soil fertility. The samples were analyzed in order to choose the fertilizer treatments. On the basis of the results of soil analysis, which was performed at the soil laboratory in the city of Sari, it was recommended that 250,70 , and $240 \mathrm{Kg}$ of urea, concentrated superphosphate, and potassium sulfate, respectively, should be applied per hectare. The soil at the site of the experiment had a loamy texture consisting of $48 \%$ sand, $35 \%$ silt, and $17 \%$ clay. It had a $\mathrm{pH}$ of 7.81 , and its electrical conductivity was $0.55 \mathrm{mmohs} / \mathrm{cm}$. The soil also contained $4.2 \%$ organic matter, $0.3 \%$ nitrogen, $17.7 \%$ phosphorus, and had 121 milligrams of potassium per kilogram. The experiment was performed in the form of factorial - split using the randomized complete block design. The major factors investigated in this project were the two silage corn cultivars of Single Cross 704 and Single Cross 770. The Single Cross 704 cultivar has been planted in the region for many years, and it has a considerable yield compared to the Single Cross 770 cultivar, which was recently imported to the country and planted by the Dash - te- Naz Agricultural Company. The sub-factors included three levels of applied nitrogen: the control treatment B1 receiving no nitrogen, treatment 
$\mathrm{B} 2$ receiving $250 \mathrm{Kg}$ nitrogen per hectare (on the basis of the results of the soil analysis and the recommended fertilizer formula), and treatment B3 receiving $350 \mathrm{Kg}$ of nitrogen per hectare. Nitrogen was applied in the form of urea. The three plant density levels were $\mathrm{C} 1, \mathrm{C} 2$, and C3, with 75000, 85000, and 95000 plants per hectare, respectively (the plants on the lines were 17.7, 16.5, and $14 \mathrm{~cm}$ apart, respectively). Every experimental plot included four lines of plants, each line was 6 meters long, and adjacent lines were $75 \mathrm{~cm}$ apart. The replications were 4 lines apart from each other to prevent any possible influences coming from the fertilizer treatments. Since there was a uniform distance between the lines $(75 \mathrm{~cm})$, the distance between plants on the lines varied so as to have the plant densities we wanted to study. The seeds were planted at the depth of $5 \mathrm{~cm}$ on the July $11^{\text {th }}$ (the first month of summer) in 2010. Analysis of variance of the data was performed using the software SAS and Mstat-C, and the software SPSS was employed to determine the correlation coefficients of the traits studied. The significant interaction effects of the factors in the experiment, and comparison of the means were conducted using Duncan's test.

\section{Results and Discussion}

\subsection{Seed Yield}

Results of comparison of the means show that the effect of the cultivar on the trait of grain yield was significant at the probability level of 5 percent (Table 1). Comparison of the means of the cultivars regarding grain yield suggests that the cultivar Single Cross 704 with a yield of $12138 \mathrm{Kg}$.h was superior to the cultivar Single Cross 770 (which had a yield of $10877 \mathrm{Kg} . \mathrm{h}$ ), and that this difference was statistically significant. Hybrid cultivars, because of differences in their adaptation to the environment, differ in their yields; therefore, climatic conditions, the potential of the region, and the fertility and depth of the soil should be taken into account (Seyyedehvand et al., 2000). These results were consistent with the report submitted by Afsharmanesh (2006), but contradicted the findings of Seyed Sharifi et al. (2009).

Nitrogen application had a significant effect on grain yield at the 5\% probability level (Table 2). Comparison of the means of nitrogen levels indicated that the highest yield (12310 kg.h) was achieved with the application of $350 \mathrm{~kg} . \mathrm{h}$ of nitrogen and the lowest (10500 kg.h) was obtained in the control treatment, and that this difference in yield was statistically significant. These results are in agreement with the findings of Rezaie Soukhte Abandani et al. (2010) and Seyed Sharifi et al. (2009). Liang et al. (1992) reported that irrigation and abundant fertilizers were needed, and the required heat had to be met, in order to achieve the maximum grain yield. The results we obtained also suggested that the effect of the factor of plant density on grain yield was significant at the one percent probability level (Table 1). The maximum and the minimum grain yields, 12500 and $11080 \mathrm{~kg} . \mathrm{h}$ were obtained at the densities of 95000 and 75000 plants per hectare, respectively. Although this difference in yield, resulting from the difference between the densities of 85000 and 95000 plants per hectare, was not statistically significant, these results are consistent with the findings of Taherkhani et al. (2007), Saberi et al. (2006) and Naderi et al. (2006); but Amjadi et al. (2007) stated that, in their research, grain yield was not statistically influenced by plant density.Baradaran et al. (2006) reported that with an increase in the density of plants the number of seeds per corn ear decreased; however, they added that the increase in the number of plants per unit area of land compensated for the decrease in the yield of each plant.

The interaction effects of all the treatments were significant at the 5\% probability level, with the exception of those of (cultivar ${ }^{x}$ plant density).

$<$ Table $1>$

\subsection{Plant Height}

Results of analysis of variance of the data showed that the individual effects of the factors of cultivar and plant density on the trait of plant height were significant at the probability levels of $5 \%$ and $1 \%$, respectively, while the effects of the nitrogen treatment and the interaction effects of cultivar, nitrogen, and plant density on plant height were not statistically significant (Table 1). According to the results of comparison of the means, the cultivar Single Cross 770, with a height of $275.66 \mathrm{~cm}$, was taller than the cultivar Single Cross 704, which had a height of $267.55 \mathrm{~cm}$. The difference between the heights of these two cultivars was statistically significant (Table 2). These results were in agreement with the report given by Iptas et al (2002).

The maximum height of plants among the nitrogen treatments $(272.83 \mathrm{~cm})$ was achieved when $250 \mathrm{~kg} . \mathrm{h}$ of nitrogen was applied, and the shortest plants $(270.75 \mathrm{~cm})$ belonged to the control treatment, but the differences in the heights of the plants in the nitrogen treatments were not statistically significant. These results agree with the findings of Turgut (1998) and Keshkin et al. (2005), and Amanullah et al. (2009). Results of our experiment also suggest that the maximum and the minimum plant heights of 278.20 and $266.37 \mathrm{~cm}$ were 
obtained at densities of 95000 and 75000 plants per hectare, respectively, but that the difference in height of plants at 75000 and 85000 plants per hectare was not statistically significant. The increase in plant height at high plant densities could be due to the escape of plants toward sunlight. These results are compatible with the findings of Ayub et al. (1999), Saberi et al. (2006), and Khalili Mahalleh et al. (2006); however, Ramazani et al. (2011) stated in their research that the height of the plants were not statistically influenced by plant density.

\subsection{Corn Ear Diameter}

There were no statistically significant differences among the cultivars with respect to the diameter of corn ears at the $1 \%$ probability level (Table 1). Comparison of the means of the cultivars regarding corn ear diameter suggested that the cultivar Single Cross 704 with a corn ear diameter of $4.75 \mathrm{~cm}$ was superior to the cultivar Single Cross 770, which had a corn ear diameter of $4.59 \mathrm{~cm}$, and that this difference was statistically significant. Results of our research were not in agreement with the findings of Seyed Sharifi et al. (2009), but Gozubenli et al. (2001) and Konuskan (2001) showed that the diameter of corn ears was influenced by the genotypes of the cultivars.

The effects of the nitrogen applied on the diameter of corn ears were significant at the probability level of $1 \%$ (Table 1). Comparison of the means of the rates of nitrogen applied confirmed that the diameter of corn ears reacted positively to an increase in the rate of nitrogen application, so that the maximum diameter of corn ears $(4.74 \mathrm{~cm})$ was achieved when $350 \mathrm{Kg}$ of nitrogen per hectare was applied, and the minimum of $4.59 \mathrm{~cm}$ was obtained in the control treatment. The rates of applying 250 and $350 \mathrm{~kg}$ of nitrogen per hectare were significantly different with respect to the diameter of corn ears. These results agree with the findings of Rezaie Soukhte Abandani et al. (2010) and Seyed Sharifi et al. (2009); however, Turgut et al. (2001) and Singh et al. (2002) reported that the rates of nitrogen application affected the diameter of corn ears, so that the ears with the smallest diameter were observed when the highest rate of nitrogen was applied.

The effects of plant density on the diameter of corn ears were significant at the $1 \%$ probability level (Table 1). The maximum and the minimum diameter of corn ears $(4.75$ and $4.60 \mathrm{~cm})$ were observed at the densities of 75000 and 95000 plants per hectare, respectively. Although the difference between the densities of 85000 and 95000 plants per hectare regarding the diameter of corn ears was not statistically significant, our results are compatible with the findings of Feizbakhsh et al. (2007). The results we obtained also showed that none of the interaction effects of the treatments on the diameter of corn ears was significant (Table 1).

\subsection{Corn Ear Length}

Results of analysis of variance showed that the cultivars were not significantly different with respect to the length of corn ears (Table 1). Comparison of the means of the cultivars regarding the length of corn ears indicated that the cultivar Single Cross 704 with a corn ear length of $16.58 \mathrm{~cm}$ was superior to the cultivar Single Cross 770 which had a corn ear length of $16.54 \mathrm{~cm}$, although this difference was not statistically significant . These results are not compatible with the findings of Seyed Sharifi et al. (2009), and Turgut et al. (2004).

The effects of the rates of nitrogen application on the length of corn ears were significant at the $1 \%$ probability level (Table 1). Comparison of the means of the rates of nitrogen application indicated that the maximum corn ear length of $17.15 \mathrm{~cm}$ was achieved with the nitrogen application rate of $350 \mathrm{~kg} . \mathrm{h}$, and the minimum of 15.69 $\mathrm{cm}$ was obtained in the control treatment. The rates of 250 and $350 \mathrm{~kg}$ of nitrogen per hectare were not significantly different regarding the length of corn ears (Table 2).. These results are in agreement with the findings of Rezaie Soukhte Abandani et al. (2010), Seyed Sharifi et al. (2009), Chandel and Kushwaha (1997), and Sahu (2006).

The effects of plant density on corn ear length were significant at the $1 \%$ probability level (Table 1 ). In our study, we found that the maximum and the minimum corn ear lengths of 17.04 and $15.93 \mathrm{~cm}$ were obtained at the densities of 75000 and 95000 plants per hectare, respectively. Feizbakhsh et al. (2007) observed that with an increase in plant density the wet weight of the ears went up, but the corn ear length declined. Noormohammadi (1997) had previously reported similar results.

The interaction effects of plant density and nitrogen, and the three - way effects of cultivar and plant density and nitrogen on corn ear length, were significant at $5 \%$ probability level (Table 1).

$<$ Table 2>

\subsection{The Number of Seed Rows in Corn Ears}

In this study, it was found that the effects of the cultivars on the feature of the number of seed rows in corn ears were not significant (Table 1). Comparison of the means of the cultivars with respect to the number of seed rows 
suggested that the cultivar Single Cross 704 with 15.28 seed rows was superior to the cultivar Single Cross 770 with 14.96 seed rows, although this difference was not statistically significant (which indicates that this component of the yield is relatively constant). These results conform to the findings of Seyed Sharifi et al. (2009) and Afsharmanesh (2006).

The rate of nitrogen application had no significant effects on the number of seed rows of the corn ears at the $5 \%$ probability level (Table 2). Comparison of the means of the rates of nitrogen application showed that the largest number of seed rows (15.43) was achieved at the nitrogen application rate of $350 \mathrm{~kg} . \mathrm{h}$, and the smallest number of seed rows (14.93) at $250 \mathrm{~kg} . \mathrm{h}$ (although this difference was not statistically significant). These results agree with the findings of Seyed Sharifi et al (2009).

Comparison of the means of the rates of nitrogen application also indicates that the effects of the plant density treatment on the number of seed rows were significant at the $1 \%$ probability level (Table 1). The maximum and the minimum numbers of seed rows of 15.74 and 14.48 were observed at densities of 75000 and 95000 plants per hectare, respectively. These results are not in agreement with the findings of Feizbakhsh et al. (2006) who stated that the number of seed rows was not statistically influenced by any of the factors studied.

In our experiment, the interaction effects of the treatments on the trait of the number of seed rows were not significant (Table 1).

\subsection{The Number of Seeds per Seed Row}

Results of analysis of variance of the data suggest that the cultivars were significantly different at the $1 \%$ probability with respect to their effects on the number of seeds per seed row (Table 1). Comparison of the means of the cultivars indicated that the cultivar Single Cross 704 with 37 seeds per seed row was superior to the cultivar Single Cross 770 with 32.34 seeds per seed row, and that this difference was statistically significant. These results are compatible with the findings of Seyed Sharifi et al. (2009) and Afsharmanesh (2006).

The effects of the rate of nitrogen application on the number of seeds per seed row at the $1 \%$ probability level were statistically significant (Table 1). Comparison of the means of the rates of nitrogen application showed that the largest number of seeds per seed row (36.83) was obtained at $350 \mathrm{~kg} . \mathrm{h}$ of nitrogen and the smallest (31.95) in the control treatment. The effects of the rates of application of 250 and $350 \mathrm{~kg} . \mathrm{h}$ nitrogen per hectare on the number of seeds per seed row were not significantly different from each other. These results are in agreement with the findings of Rezaie Soukhte Abandani et al (2010) and Seyed Sharifi et al (2009).

Plant density had a significant effect on the number of seeds per seed row at the 5\% probability level (Table 1). Results of our research indicate that the largest and the smallest number of seeds per seed row (36.15 and 33.8) were observed at the densities of 75000 and 95000 plants per hectare, respectively, and that this difference was statistically significant. These results conform to the findings of Feizbakhsh et al (2007), Saberi et al (2007), and Afsharmanesh (2005). Tito and Gardiner (1998) found that the number of seeds per seed row declined at high plant densities due to the decrease in fertilization rate. In our study, the interaction effects of the treatments on the number of seeds per seed row were significant at the $5 \%$ probability level.

\subsection{The Number of Seeds per Corn Ear}

According to the results of analysis of variance of the data, the number of seeds per corn ear was influenced by the cultivars at the $1 \%$ probability level (Table 1). Comparison of the means of the cultivars confirmed that the cultivar Single Cross 704 with 552.76 seeds per corn ear was superior to the Cultivar Single Cross 770 which had 496.02 seeds per corn ear, and that this difference was statistically significant. The effects of the rates of nitrogen application on the number of seeds per corn ear were significant at the $1 \%$ probability level (Table 1). Comparison of the means of the rates of nitrogen application indicated that the largest number of seeds per corn ear (561.1) was obtained at the application rate of $350 \mathrm{~kg}$. h of nitrogen, and the smallest number in the control treatment. Ghasemi Pirbalouti (2002) reported that the availability of nutrients, especially nitrogen, in the critical period of seed formation (that is, one to two weeks before and up to three weeks after the silk formation stage) influenced the number of seeds per corn ear by increasing the rate of growth of the plants, and that this brought about a strong correlation between the number of the seeds in the corn ears and the availability of nitrogen. In numerous studies, the positive effects of nitrogen application on the increase in the number of seeds per corn ear has been reported (Osborne et al., 2002). The results we obtained are also in conformity with the findings of Rezaie Soukhte Abandani et al (2010) and Seyed Sharifi et al (2009).

Plant density had a significant effect on the number of seeds per corn ear at the $1 \%$ probability level (Table 1). Results from our experiment show that the largest and the smallest numbers of 568.1 and 489.4 seeds per corn ear were obtained at densities of 75000 and 95000 plants per hectare, respectively, and that these numbers were 
significantly different from each other. It seems that with an increase in plant density the competition among plants for obtaining nutrients increased, and hence smaller seeds were formed on corn ears, and this led to a decrease in the diameter of corn cubs. Sadeghi et al (1999), Feizbakhsh et al. (2007), and Bobu and Mitra (1989) observed similar results. In the present study, we found that all interaction effects of the treatments on the number of seeds per corn ear were significant at the $5 \%$ probability level (Table 1 ).

\subsection{The 1000 - Seed Weight}

Results of analysis of variance of the data indicated that the individual effects of the factor of cultivar on the feature of the 1000 - seed weight was significant at the $1 \%$ probability level (Table 1). Comparison of the means of the cultivars with respect to the 1000 - seed weight showed that the cultivar Single Cross 704 with $313.6 \mathrm{~g}$ was superior to the cultivar Single Cross 770 which had $255 \mathrm{~g}$, and that the difference was statistically significant. These results are similar to those reported by Brardaran et al. (2006) (Table 2). It seems that in the cultivar 770 more photosynthates were transferred to the seeds and that the 1000 - seed weight was more constant than the other components of the yield (Afsharmanesh, 2006).

Rates of nitrogen application had a significant effect on the 1000 - seed weight at the $1 \%$ probability level (Table 1). Comparison of the means of the rates of nitrogen application revealed that the maximum 1000 - seed weight of $300.8 \mathrm{~g}$ was obtained by applying $350 \mathrm{~kg}$ of nitrogen per hectare, and the minimum 1000- seed weight $(269.6 \mathrm{~g})$ belonged to the control treatment, but that the two treatments of applying $350 \mathrm{~kg}$ of nitrogen per hectare and not applying nitrogen were not significantly different from each other with respect to the 1000 - seed weight (Table 2). Osborne et al. (2002) and Johardt and Endereldy (1993) reported that the yield, the number of the seeds, and the 1000 - seed weight increased when more nitrogen was applied; and the findings of Rezaie Soukhte Abandani et al. (2010) confirm their reports.

Plant density had a significant effect on the 1000 - seed weight at the $1 \%$ probability level (Table 1 ). In our study, we found that the 1000 - seed weight went up when plant density increased (the largest and the smallest 1000 - seed weights of 297.5 and $268.8 \mathrm{~g}$ were obtained at the densities of 75000 and 95000 plants per hectare, respectively), but that the difference between the effects of the densities of 75000 and 95000 plants per hectare on the 1000 - seed weight were not statistically significant. Possibly, low plant density had no effect on the 1000-seed weight; however, at higher plant densities, due to increased competition among plants, less photosynthates are produced, on the one hand, and on the other hand, the decline in the number of seeds per corn ear causes source limitations, a decrease in the assigned photosynthetic, and the re-transfer of these substances to the seeds; and hence, the end results of these factors lead to a decline of the 1000 - seed weight at high plant densities.

All the interaction effects of the treatments, except (cultivar ${ }^{x}$ nitrogen), had significant effects on the 1000 -seed weight at the level of $5 \%$ probability level (Table 1 ).

\subsection{The Diameter of Corn Cobs}

Results of analysis of variance of the data showed that the cultivars were not significantly different regarding the diameter of the corn cobs (Table 1). In our study, we observed that the cultivar Single Cross 770 with a corn cob diameter of $2.38 \mathrm{~cm}$ was superior to the cultivar Single Cross 704 which had a corn cob diameter of $2.34 \mathrm{~cm}$, although this difference was not statistically significant.

The effects of the rates of nitrogen application on the diameter of corn cobs were significant at the 5\% probability level (Table 1). Comparison of the means of the application rates of nitrogen revealed that the maximum corn cob diameter of $2.39 \mathrm{~cm}$ was obtained at the rate of $350 \mathrm{~kg}$ of nitrogen per hectare, that the minimum diameter of $2.31 \mathrm{~cm}$ belonged to the control treatment, that this difference was significant, and also that the effects of applying 250 and $350 \mathrm{~kg}$ of nitrogen per hectare on the diameter of the corn cobs were not statistically significant (Table 2).

According to the results of our experiment, plant density had a significant effect on corn cob diameter at the $5 \%$ probability level. Comparison of the means of the data indicated that the maximum corn cob diameter of $2.41 \mathrm{~cm}$ was achieved at the density of 75000 plants per hectare, and the minimum of $2.32 \mathrm{~cm}$ at 95000 plants per hectare, but that this difference was not statistically significant.

In our experiment, we found that the interaction effects of the treatments on corn cob diameter were not significant (Table 1).

\subsection{Investigation of the Results of the Correlation Coefficients}

Results of individual correlation coefficients of the traits studied suggest that seed yield has the strongest positive and significant correlation with the trait of the 1000 - seed weight $\left(0.539^{*}\right)$, with the corn ear length 
$\left(0.52^{*}\right)$, and with the number of seed rows per corn ear $\left(0.453^{*}\right)$. It was also found that the 1000 -seed weight had the strongest positive and significant correlation with the diameter of corn ears $\left(0.700^{*}\right)$, the length of corn ears $\left(0.386^{*}\right)$, and the number of seed rows per corn ear $\left(0.367^{*}\right)$. Furthermore, the number of seeds per corn ear had the strongest positive and significant correlation with the features of the number of seeds per seed row $\left(0.882^{*}\right)$, the length of the corn ears $\left(0.737^{*}\right)$, and the number of seed rows per ear corn $\left(0.457^{*}\right)$ (Table 3$)$.

$<$ Table $3>$

\section{References}

Afsharmanesh, GH. (2003). Study of the effects of plant density on seeds of the summer crop of corn cultivars in the region of Jiroft, the scientific. Research Journal of Agricultural Sciences, 2(4), 123-127.

Ajamnouroozi, H., \& Bohrani, J. (1998). The effects of planting configuration and plant density on the yield and yield components of the late maturing grain corn cultivar of S.C 704 and the intermediate maturing corn cultivar of S. C 704 in the region of Aliabad Kamin in the province of Fars. In the Proceeding $5^{\text {th }}$ Congress of Iranian Agronomy and Plant breeding, Karaj, Iran. P 380.

Amanullah., Marwat, B., \& Shah, P. (2004). Nitrogen levels and its time of application Influence leaf area, height and biomass of maize planted at low and high density.

Amjadi, S., Khojavinezhad, \& Maghsoodi Moaddab, Gh. A. (2007). The effect of plant density and application of nitrogen at different growth stages on the yield and its components in the corn cultivar 704 in Kerman, In Proceeding $10^{\text {th }}$ Iranian Congress of Agronomy Sciences and Plant breeding, Karaj, Iran. 326p.

Anonymous. (2003). The corn production situation in the country and the need for implementing the Corn Project, the Ministry of Agricultural Jihad (Deputy Ministry of Agronomy). pp 721.

Ayub, M., Mahmood, R., Tanveer, A., \& Shahrar, M. S. (1999). Effect of seeding density on the fodder yield and quality of two maize Varieties. Journal of Biological Sciences, 2(3), 664-666.

Baradaran, R., Javadi, H., \& Moosavi, GH. (2006). Study of the effect of plant density on the yield and its components in the sorghum grain cultivars under the weather conditions of Birjand. Research Journal of Agricultural Sciences, 1(3), 221-225.

Bobu, K. S \& S. K. Mitra. (1989). Effects of plant density on grain yield of maize during rabi season. Madras Agricultural Journal, 79, 290- 292.

Feizbakhsh, M., Nemati, H., Mokhtarpour, A., Mossavat, A., Saberi, F., \& Sheikh. (2007). The effect of eliminating shoots and that of plant density on the yield and its components of sweet corn. Journal of Constructive Research in Agronomy and Horticulture, 77, 66-69.

Ghasemi Pirbalouti, A. (2002). The effect of different rates of nitrogen application on the mode of appropriation of dry matter in grain corn cultivar of S.C. 704 in the region of Varamin. M.Sc. thesis in Agronomy, Tehran University, $\mathrm{Pp} 98$.

Gozubenli, H., Ulger, A.C. \& Senser, O. (2001). The effect of different nitrogen doses on grain field and yield-related characters of some genotypes grown as second crop. J. Agric. Fac., 16, 39-48.

Iptas, S., \& Acar, A, A. (2006). Effects of hybrid and row spacing on maize forage yield and quality. Plant Soil Environ, 52(11), 515- 522.

Keskin, B., Akdeniz, H., Ibrahim, Hakkiyilmaz, I., \& Mettin Turan, N. (2005). Yield and quality of forage corn (Zea mays L.) as influenced by cultivar and Nitrogen rate. Journal of Agronomy, 4(2), $138-141$. http://dx.doi.org/10.3923/ja.2005.138.141

Khalili Mahalleh, J., Tajbakhsh, M., Fayyazmoghaddam, A., \& Siadat, A. (2007). The effect of plant density on the quantitative and qualitative features of fodder sorghum planted as a second crop. Journal of Constructive Research in Agronomy and Horticulture, 75(2), 98-102.

Kiniry, J. R. C. Tischler. W. D. Rosenthal \& T. J. Gerik. (1992). Non structural carbohydrate utilization by sorghum and maize shaded during growth. Crop Sci., 32, 131-137. http://dx.doi.org/10.2135/cropsci1992.0011183X003200010029x

Konuskan, O. (2000). Effects of plant density on yield and yield related characters of some maize hybrids grown in Hatay conditions as second crop. M.Sc. Thesis, Science Institute, M.K.U., 71 p.

Kresovic, B., Tolimir \& Pajic. (1997). Growing of sweet corn as a second or stubble crop. J. of Sci. Agric. Aes., 48, 23-30. 
Kushwaha, H. S. \& A.S. Chandel. (1997). Effect of soybean (Glycine max Merril) intercropping under different nitrogen level on yield, yield attributes and quality of maize (Zea mays L.). Ind. J. Sci., 67(6): 249-252.

Liang, B. C., Millard, M. R., \& Machenzie, A. F. (1992). Effect of hybrid. Population density, fertilization and irrigation on grain corn (Zea mays L.) in Quebec. Can. J. of Plant Sci., 72, 1163-1170. http://dx.doi.org/10.4141/cjps92-142

Naderi, F., Rafiee, M., \& Siadat, S. A. (2005). The effects of planting date and plant density on the yield and its components in corn planted as a second crop in the weather conditions of Khorramabad. Journal of Constructive Research, 75, 69-74.

Natarajan, M. (1989). Cropping system some concepts and methodologies. Spatial arrangement of the component crop in developing inter. I. N: S. R. Waddington, A. F. E. Palmar, and O. T; Edje (eds). Sponsored CYMMIT, CIAT.AND government of Malowi. pp. 680-730.

Nielson, R. L. (1988). Influence of hybrids and plant density on grain yield and stalr breakage in corn growth in 15-inch row spacing. J. Prod. Agric, 190-195.

Noormohammadi, Gh. A. \& A. Siadat Kashani. (2001). Grain Crops, volume 1, third edition, Chamran University Publications. Pp 236.

Osborne, S. L., Scheppers, J. S., Francis, D. D. \& Schlemmer, M. R. (2002). Use of spectral Radiance to in-season biomass and grain yield in nitrogen and water-stressed corn. Crop Sci., 42, 165-171. http://dx.doi.org/10.2135/cropsci2002.0165

Ramezani. M., Rezaie Soukhte- Abandani. R., Mobasser. H. R., \& Amiri.E. (2011). Effects of row spacing and plant density on silage yield of corn (Zea mays L. cv. Sc 704) in two plant pattern in North of Iran. African Journal of Crop Science, 6(5), 1128-1133.

Rezaie Soukhte Abandani, R., Cherati Araee, A., Akbari Nodehi, D., Mobasser, H. R., \& Ramezani, M. (2009). Study of the effects of irrigation interval and rates of nitrogen application on the yield and its components in the corn cultivar 704 in the region of Mazandaran. Research Journal of Agricultural Sciences, 2(3), 111-115.

Bureau of the Corn Project, the Ministry of Agricultural Jihad. (2005).

Sadeghi, A. (2003). The effect of the planting configuration on the seed yield of the late maturing corn hybrid cultivar KSC 404 in the province of Kermanshah, the Journal of Seedlings and Seeds, 19(1), 4-7.

Sahu, B. (2006). Yield and economics of intercropping legumes in maize (Zea mays L.) under rainfed conditions. Ind. J. Agri. Sci., 76(1), 554-556.

Seyed Sharifi, Raouf., \& Taghizade, Reza. (2009). Response of maize (Zea mays 1.) cultivar to different of Nitrogen fertilizer. Journal of Agriculture and environmental, 7(3-4), 518-523.

Seyyedeh Vand, M., Valizadeh, J., Ghannadha, M., \& Bankeh Saz, A. (2000). Study of the change in the planting pattern and plant density on the yield of the corn cultivar Single Cross 704 . In the Proceeding $6^{\text {th }}$ Iranian Congress of Agronomy and Plant breeding, Babolsar, Iran. P 299.

Singh, D. P., Rana, N. S. \& Singh, R. P. (2000). Growth and yield of winter maize (Zea mays L.) as influenced by intercrops and nitrogen application. Indian J. Agron., 45, 515-519.

Solan, R. J., R.P. Patterson \& T.E. Cater. (1990). Field drought tolerance of soybean plant introduction. Crop Sc., 30, 53-85.

Taherkhani, M., \& Afsharmanesh, Gh. (2007). Study of the effect of the planting pattern, the distance between plants, and the plant density on corn seed yield. Journal of Constructive Research, 77, $29-34$.

Torbert, H. A., Potter, K. N. \& Morrison, J. E. (2001). Tillage system, fertilizer nitrogen rate and timing effect on corn yields in the Texas Black land prairie. Agron. J., 93, 1119-1124. http://dx.doi.org/10.2134/agronj2001.9351119x

Turgut, I. (1998). Bazı melez misır (Zea mays indentata Sturt.) Cesitlerinde farklı azot dozlarının verim ve verim ogeleri üzerine etkisi. Ulud.Univ. Zir.Fak. Derg. 14, 137-147.

Turgut, I. (2004). Effects of plant populations and nitrogen doses on fresh ear yield and yield components of sweet corn (Zea mays saccharata Sturt.) grown under Bursa conditions. Turk. J. Agric. For., 24, 341-348. 
Table 1. Analysis of variance of the features studied

\begin{tabular}{|c|c|c|c|c|c|c|c|c|c|}
\hline $\begin{array}{l}\text { Source of } \\
\text { change }\end{array}$ & Grain yield & $\begin{array}{l}\text { Plant } \\
\text { height }\end{array}$ & $\begin{array}{l}\text { Corn } \\
\text { ear } \\
\text { diameter }\end{array}$ & $\begin{array}{l}\text { Corn } \\
\text { ear } \\
\text { length }\end{array}$ & $\begin{array}{l}\text { Number } \\
\text { of } \\
\text { seed/row }\end{array}$ & $\begin{array}{l}\text { Number } \\
\text { of seeds/ } \\
\text { row }\end{array}$ & $\begin{array}{l}\text { Number of } \\
\text { seeds/ corn } \\
\text { ear }\end{array}$ & $\begin{array}{l}\text { The } 1000 \\
\text { seed } \\
\text { weight }\end{array}$ & $\begin{array}{l}\text { Diameter } \\
\text { of The } \\
\text { Corn } \\
\text { Cob }\end{array}$ \\
\hline Block & 39753582.9 & 3608.14 & 0.175 & 4.19 & 0.657 & 33.12 & 10312.45 & 86.86 & 0.097 \\
\hline $\begin{array}{l}\text { Factor A } \\
\text { (cultivar) }\end{array}$ & $5384750.1 *$ & $1184.22 *$ & $0.454 * *$ & 0.030 & 1.95 & $389.71 * *$ & $57962.74 * *$ & $618.34 * *$ & 0.036 \\
\hline $\begin{array}{l}\text { Factor B } \\
\text { (nitrogen) }\end{array}$ & $72385585^{*}$ & 28.388 & $0.128^{* *}$ & $13.48^{* *}$ & 1.73 & $135.19^{* *}$ & $41596.42 * *$ & $59.18^{* *}$ & $0.051^{*}$ \\
\hline $\begin{array}{l}\text { Factor C } \\
\text { (plant } \\
\text { density) }\end{array}$ & $4138597.8^{* *}$ & $873.513^{* *}$ & $0.145^{* *}$ & $7.46^{* *}$ & $9.68^{* *}$ & $70.25^{*}$ & $53708.77 * *$ & $50.59 * *$ & $0.051^{*}$ \\
\hline $\mathrm{AB}$ & $4143894.3 * *$ & 48.722 & 0.068 & 0.863 & 1.53 & $14.79 *$ & $2170.78 *$ & $2.68 *$ & 0.037 \\
\hline $\mathrm{AC}$ & 20261.1 & 110.930 & 0.004 & 0.168 & 0.238 & $0.07 *$ & $253.61 *$ & i. $43^{*}$ & 0.010 \\
\hline $\mathrm{BC}$ & $468975.2 *$ & 41.451 & 0.005 & $0.052 *$ & 0.342 & $1.17 *$ & $950.16^{*}$ & 5.55 & 0.0054 \\
\hline $\mathrm{ABC}$ & $320531.9 *$ & 109.368 & 0.001 & $0.310^{*}$ & 0.114 & $3.05^{*}$ & $917.20 *$ & $3.63 *$ & 0.0043 \\
\hline $\begin{array}{l}\text { Coefficient } \\
\text { of } \\
\text { variation }\end{array}$ & 13.36 & 4.01 & 2.65 & 4.65 & 4.55 & 6.03 & 6.42 & 6.29 & 4.42 \\
\hline
\end{tabular}

The symbols * and ${ }^{* *}$ stand for significant differences at $5 \%$ and $1 \%$ probability levels, respectively.

Table 2. Comparison of the means of the traits studied

\begin{tabular}{|c|c|c|c|c|c|c|c|c|c|c|}
\hline \multirow{2}{*}{\multicolumn{2}{|c|}{ Treatment }} & $\begin{array}{l}\text { Seed } \\
\text { yield }\end{array}$ & $\begin{array}{l}\text { Plant } \\
\text { height }\end{array}$ & $\begin{array}{l}\text { Corn ear } \\
\text { diameter }\end{array}$ & $\begin{array}{l}\text { Corn } \\
\text { ear } \\
\text { length }\end{array}$ & $\begin{array}{l}\text { No. of } \\
\text { seed } \\
\text { rows }\end{array}$ & $\begin{array}{l}\text { No. of } \\
\text { seeds per } \\
\text { row }\end{array}$ & $\begin{array}{l}\text { No. of } \\
\text { seeds per } \\
\text { ear }\end{array}$ & $\begin{array}{l}\text { The } 1000 \\
\text { seed } \\
\text { weight }\end{array}$ & $\begin{array}{l}\text { Corn cob } \\
\text { diameter }\end{array}$ \\
\hline & & $\mathrm{Kg} / \mathrm{ha}$ & $\mathrm{Cm}$ & $\mathrm{Cm}$ & $\mathrm{cm}$ & & & & $\mathrm{g}$ & $\mathrm{Cm}$ \\
\hline \multirow{2}{*}{\multicolumn{2}{|c|}{$\begin{array}{l}\text { Sc } 704 \\
\text { Sc770 }\end{array}$}} & $12138 \mathrm{a}$ & $267.55 b$ & $4.59 a$ & $16.58 \mathrm{a}$ & $14.96 \mathrm{a}$ & $37 \mathrm{a}$ & $552.76 \mathrm{a}$ & $255 \mathrm{~b}$ & $2.34 \mathrm{a}$ \\
\hline & & $10789 \mathrm{~b}$ & $275.66 \mathrm{a}$ & $4.75 \mathrm{a}$ & $16.45 \mathrm{a}$ & $15.28 \mathrm{a}$ & $32.34 \mathrm{~b}$ & $496.02 \mathrm{~b}$ & $313.6 \mathrm{a}$ & $2.38 \mathrm{a}$ \\
\hline \multicolumn{11}{|l|}{ Nitrogen } \\
\hline Zero & & $10500 \mathrm{c}$ & $270.75 a$ & $4.59 \mathrm{~b}$ & $15.69 b$ & $15.01 \mathrm{a}$ & $31.95 \mathrm{~b}$ & $479.2 \mathrm{c}$ & $269.6 \mathrm{~b}$ & $2.31 \mathrm{~b}$ \\
\hline 250 & & $11720 \mathrm{~b}$ & $272.83 a$ & $4.68 \mathrm{a}$ & $16.71 \mathrm{a}$ & $14.93 \mathrm{a}$ & $35.74 a$ & $532.8 \mathrm{~b}$ & $282.5 \mathrm{~b}$ & $2.38 \mathrm{a}$ \\
\hline 350 & & $12310 \mathrm{a}$ & $271.25 \mathrm{a}$ & $4.74 \mathrm{a}$ & $17.15 \mathrm{a}$ & $15.43 \mathrm{a}$ & $36.83 \mathrm{a}$ & $561.1 \mathrm{a}$ & $300.8 \mathrm{a}$ & $2.39 \mathrm{a}$ \\
\hline \multicolumn{11}{|l|}{ Density } \\
\hline 75000 & & $11080 \mathrm{~b}$ & $266.37 \mathrm{~b}$ & $4.75 \mathrm{a}$ & $17.04 \mathrm{a}$ & $15.74 \mathrm{a}$ & $36.15 \mathrm{a}$ & $568.1 \mathrm{a}$ & $297.5 \mathrm{a}$ & $2.41 \mathrm{a}$ \\
\hline 85000 & & $11730 \mathrm{a}$ & $270.25 b$ & $4.66 \mathrm{~b}$ & $16.58 b$ & $15.15 b$ & $35 \mathrm{a}$ & $530.9 \mathrm{~b}$ & $286.7 \mathrm{a}$ & $2.35 \mathrm{ab}$ \\
\hline 95000 & & $12500 \mathrm{a}$ & $278.20 \mathrm{a}$ & $4.60 \mathrm{~b}$ & $15.93 \mathrm{c}$ & $14.48 \mathrm{c}$ & $33.8 \mathrm{~b}$ & $489.4 \mathrm{c}$ & $268.8 \mathrm{~b}$ & $2.32 \mathrm{~b}$ \\
\hline $\begin{array}{l}\text { Cultivar } \\
\text { Nitrogen }\end{array}$ & $x$ & $*$ & Ns & Ns & Ns & Ns & $*$ & $*$ & $*$ & Ns \\
\hline $\begin{array}{l}\text { Cultivar } \\
\text { Density }\end{array}$ & $\mathrm{x}$ & Ns & Ns & Ns & Ns & Ns & $*$ & $*$ & $*$ & Ns \\
\hline $\begin{array}{l}\text { Nitrogen } \\
\text { Density }\end{array}$ & $\mathrm{x}$ & $*$ & Ns & Ns & $*$ & Ns & $*$ & $*$ & Ns & Ns \\
\hline $\begin{array}{l}\text { Cultivar } \\
\text { Density } \\
\text { Nitrogen }\end{array}$ & $\begin{array}{l}\mathrm{x} \\
\mathrm{x}\end{array}$ & $*$ & Ns & Ns & $*$ & Ns & $*$ & $*$ & $*$ & Ns \\
\hline
\end{tabular}

The symbols ns, ${ }^{*}$, and $* *$ indicate not significant, significant at the $5 \%$ probability level, and significant at the $1 \%$ probability level, respectively 
Table 3. The correlation coefficients of the features studied

\begin{tabular}{|c|c|c|c|c|c|c|c|c|}
\hline Feature & $\begin{array}{l}\text { Diameter } \\
\text { of the ear }\end{array}$ & $\begin{array}{l}\text { Length } \\
\text { of the ear }\end{array}$ & $\begin{array}{ll}\text { No. of } \\
\text { seed } \\
\text { rows per } \\
\text { ear }\end{array}$ & $\begin{array}{l}\text { No. of } \\
\text { seeds per } \\
\text { seed row }\end{array}$ & $\begin{array}{l}\text { No. of } \\
\text { seeds } \\
\text { per ear }\end{array}$ & $\begin{array}{l}1000 \text {-seed } \\
\text { weight }\end{array}$ & $\begin{array}{l}\text { Diameter } \\
\text { of corn } \\
\text { cob }\end{array}$ & $\begin{array}{l}\text { Seed } \\
\text { yield }\end{array}$ \\
\hline $\begin{array}{l}\text { Diameter of } \\
\text { the ear }\end{array}$ & 1 & & & & & & & \\
\hline $\begin{array}{l}\text { Length of } \\
\text { the ear }\end{array}$ & $0.422 *$ & 1 & & & & & & \\
\hline $\begin{array}{l}\text { No. of rows } \\
\text { per ear }\end{array}$ & $0.443^{*}$ & $0.265^{*}$ & 1 & & & & & \\
\hline $\begin{array}{l}\text { No. of } \\
\text { seeds per } \\
\text { seed row }\end{array}$ & 0.081 & $0.686^{* *}$ & -0.013 & 1 & & & & \\
\hline $\begin{array}{lr}\text { No. } & \text { of } \\
\text { seeds } & \text { per } \\
\text { ear }\end{array}$ & $0.287^{*}$ & $0.737 * *$ & $0.457^{*}$ & $0.882 * *$ & 1 & & & \\
\hline $\begin{array}{l}1000 \text {-seed } \\
\text { weight }\end{array}$ & $0.700^{* *}$ & $0.386^{*}$ & $0.367^{*}$ & -0.026 & 0.163 & 1 & & \\
\hline $\begin{array}{l}\text { Diameter of } \\
\text { corn cob }\end{array}$ & $0.439^{*}$ & $0.432 *$ & $0.404 *$ & 0.154 & $0.332 *$ & $0.311^{*}$ & 1 & \\
\hline Seed yield & $0.378^{*}$ & $0.520^{* *}$ & 0.242 & $0.374 *$ & $0.453 *$ & $0.539 * *$ & $0.288^{*}$ & 1 \\
\hline
\end{tabular}

The symbols ns, $*$, and $* *$ mean not significant, significant at the $5 \%$ probability level, and significant at the $1 \%$ probability level, respectively. 